\title{
Pytania testowe
}

Poniżej zamieszczono pytania testowe umożliwiające sprawdzenie wiedzy obejmującej zagadnienia, o których jest mowa w niniejszym numerze „Hematologii”.

\section{Pytanie 1.}

Wśród wskazań do rozpoczęcia leczenia u chorych na chłoniaka grudkowego w zaawansowanym stadium klinicznym (III/IV wg klasyfikacji Ann Arbor), zgodnie z kryteriami GELF (Groupe d'Etude des Lymphomes Folliculaires), są: 1) zajęcie $\geq 3$ miejsc węzłowych, każde o rozmiarze $\geq 3 \mathrm{~cm} ; 2$ ) splenomegalia $>16 \mathrm{~cm}$ w badaniu metodą tomografii komputerowej; 3) masa węzłowa lub pozawęzłowa $\geq 5 \mathrm{~cm}$; 4) komórki chłoniaka we krwi w liczbie $>5 \mathrm{G} / 1$; 5) naciek limfocytów w szpiku $>30 \%$
A. 1), 3) i 4)
B. 1), 2) i 3)
C. 1), 2) i 4)
D. 2), 3) i 4)
E. 3), 4) i 5)

\section{Pytanie 2.}

Aktualnym standardem leczenia chorych na chłoniaka grudkowego we wczesnych stadiach klinicznych (stadium I lub II bez masywnych zmian węzłowych wg klasyfikacji Ann Arbor), zgodnie

z zaleceniami ESMO (European Society for Medical Oncology) z 2014 roku, jest:

A. Strategia watch and wait

B. Radioterapia ograniczona do miejsc zmienionych chorobowo (IF-RT, involved-field radiotherapy) w dawce 30 Gy lub strategia watch and wait

C. Immunoterapia rytuksymabem w dawce $375 \mathrm{mg} / \mathrm{m}^{2}$ (8 podań co 4 tyg.)

D. Radioterapia ograniczona do miejsc zmienionych chorobowo (IF-RT) w dawce 24 Gy; u starszych chorych $z$ przeciwwskazaniami do radioterapii możliwa jest strategia watch and wait

E. Radioterapia ograniczona do miejsc zmienionych chorobowo (IF-RT) w dawce 24 Gy, a następnie immunoterapia rytuksymabem w dawce $375 \mathrm{mg} / \mathrm{m}^{2}$ (8 podań co 4 tyg.)

\section{Pytanie 3.}

Całkowity czas przeżycia chorych na przewlekłą białaczkę szpikową w fazie przewlekłej leczonych dazatynibem, u których doszło do wzrostu zawartości dużych ziarnistych limfocytów we krwi, jest:
A. Krótszy niż u chorych bez tego powikłania, ponieważ zjawisko to sprzyja występowaniu wysięków opłucnowo-osierdziowych, często o niekorzystnym przebiegu klinicznym
B. Dłuższy w porównaniu z chorymi bez tego powikłania
C. Podobny jak u chorych bez tego powikłania
D. Indywidualnie zmienny, ponieważ zjawisko to ma charakter przemijający i nie jest istotne klinicznie
E. Znacznie krótszy niż u chorych bez tego powikłania, ponieważ jest zapowiedzią wystąpienia bardziej zaawansowanych faz choroby 


\section{Pytanie 4.}

U chorych na przewlekłą białaczkę szpikową w fazie przewlekłej leczonych dazatynibem można wykazać obecność klonalnej populacji limfocytów o fenotypie T lub/i komórek naturalnej cytotoksyczności (NK, natural killer). Proszę wskazać prawidłową odpowiedź.
A. W większości przypadków zawartość we krwi limfocytów o fenotypie T lub/i komórek NK zwiększa się w trakcie pierwszych 1-9 miesięcy leczenia
B. Wzrost zawartości we krwi limfocytów o morfologii dużych ziarnistych limfocytów dotyczy 30-60\% chorych
C. Występowanie podobnego zjawiska zaobserwowano u chorych na ostrą białaczką limfoblastyczną z obecnym chromosomem Philadelphia leczonych dazatynibem
D. Mobilizacji podlegają naturalne NK, cytotoksyczne komórki T (NK T), limfocyty B oraz komórki T $\gamma \delta+$
E. Wszystkie odpowiedzi są prawidłowe

\section{Pytanie 5.}

U chorych na przewlekłą białaczkę szpikową w fazie przewlekłej leczonych imatynibem, z objawami nieskuteczności/nietolerancji terapii, zastosowanie w II linii terapii inhibitora kinaz tyrozynowych II generacji wiąże się z ryzykiem ich ponownego wystąienia u około:
A. $30 \%$ pacjentów
B. $40 \%$ pacjentów
C. $50 \%$ pacjentów
D. $10 \%$ pacjentów
E. $25 \%$ pacjentów

\section{Pytanie 6.}

Kariotyp 47,XY,+Y[2]/45,XY,-21[6]/46,XY u chorego na przewlekłą białaczkę szpikową leczonego dazatynibem w 3 . linii terapii świadczy o:
A. Całkowitej remisji cytogenetycznej
B. Całkowitej remisji cytogenetycznej choroby z obecnością aberracji cytogenetycznych w klonie Phila- delphia-ujemnym
C. Całkowitej remisji cytogenetycznej choroby z obecnością aberracji cytogenetycznych w klonie Phila- delphia-dodatnim
D. Ewolucji klonalnej przewlekłej białaczki szpikowej
E. Pojawieniu się źle rokujących aberracji typu major

\section{Pytanie 7.}

U chorych, u których podejrzewa się infekcję odcewnikową, centralny cewnik żylny należy usunąć: 1) u wszystkich chorych; 2) u chorych z posocznicą i objawami niestabilności hemodynamicznej; 3) u chorych stabilnych hemodynamicznie $z$ udokumentowaną infekcją odcewnikową koagulazo-ujemnymi gronkowcami; 4) u chorych z objawami zakażenia okolicy wejścia lub kanału cewnika; 5) u chorych $\mathrm{z}$ udokumentowaną infekcją odcewnikową gronkowcem złocistym lub pałeczką ropy błękitnej
A. 1)
B. 3) i 5)
C. 2), 3), 4) i 5)
D. 2), 4) i 5)
E. 2), 3) i 5) 


\section{Pytanie 8.}

Badanie CMV (cytomegalovirus) DNA w popłuczynach oskrzelowo-pęchęrzykowych może służyć:
A. Wykryciu choroby CMV u chorego z objawami śródmiąższowego zapalenia płuc ze względu na wysoką wartość predykcyjną wyniku dodatniego
B. Wykluczeniu zakażenia CMV jako przyczyny zapalenia płuc ze względu na wysoką wartość predykcyjną wyniku ujemnego
C. Wykryciu lub wykluczeniu choroby CMV u chorego $\mathrm{z}$ objawami śródmiąższowego zapalenia płuc ze względu na wysokie wartości predykcyjne wyników dodatniego i ujemnego
D. Wykryciu bezobjawowej infekcji CMV
E. Badanie to nie jest przydatne w diagnostyce infekcji lub choroby CMV

\section{Pytanie 9.}

Wskazaniami do leczenia chorych na białaczkę z dużych ziarnistych limfocytów T(T-LGL) są:
A. Objawowa lub wymagająca przetoczeń koncentratu krwinek czerwonych niedokrwistość
B. Umiarkowana neutropenia $(0,5-1,0 \mathrm{G} / \mathrm{l})$ bez nawracających infekcji
C. Wspólistniejące choroby autoimmunizacyjne wymagające leczenia
D. Prawidłowe są odpowiedzi A i C
E. Prawidłowe są odpowiedzi A, B i C

\section{Pytanie 10.}

Monoklonalna limfocytoza z dużych ziarnistych limfocytów nie może być reakcją na:
A. Obecność choroby autoimmunizacyjnej
B. Obecność infekcji wirusowych
C. Szczepienie przeciwko grypie
D. Prawidłowe są odpowiedzi A i B
E. Prawidłowe są odpowiedzi A, B i C 